\title{
ANALISIS FAKTOR YANG MEMPENGARUHI MUTU PELAYANAN KESEHATAN TERHADAP KEPUASAN PASIEN DI PUSKESMAS RAWAT INAP KABUPATEN PASAMAN 2019
}

\author{
Herman Harun ${ }^{1}$, Wijayantono ${ }^{2}$ \\ Sekolah Tinggi Ilmu Kesehatan Fort De Kock Bukittinggi ${ }^{1}$, \\ Poltekkes Kemenkes Padang ${ }^{2}$ \\ hermanharun007@gmail.com
}

Submitted: 05-08-2019, Reviewer: 13-08-2019, Accepted: 21-10-2019

\begin{abstract}
The quality of health services at the Health Care Centre is the final product of the complex interactions and dependencies between various components or aspects of service. Quality of health care centre services will be one of the determinants of efforts to improve public health status. The purpose of this study is to analyze the quality of health services with patient satisfaction at inpatient health centers in Pasaman 2019. This type of research is descriptive analytic with crossectional study design. The study sample was 195 respondents in Healt Care Centre at Pasaman Regency. To find out the effect of quality of health services on patient satisfaction, an analysis was carried out with a chi-quare test and Multiple Logistic Regression Test. with a 95\% confidence level. The results showed that after analysis using the chi-square test, there was a relationship of reliability (0.023), responsiveness (0.018), assurances (0.009), empathy (0.005), and tangibles (0.0005) with patient. Multivariate results were obtained from 5 variables, 1 variable that affected patient satisfaction was tangibles (0,0005). Health Officers can identify and evaluate the quality of health services with the level of patient satisfaction, especially at the Health Care Centre.
\end{abstract}

Keyword : : Quality of Health Services, Patient Satisfaction

\begin{abstract}
ABSTRAK
Mutu pelayanan kesehatan di puskesmas adalah produk akhir dari interaksi dan ketergantungan yang rumit antara berbagai komponen atau aspek pelayanan. Pelayanan puskesmas yang bermutu akan menjadi salah satu faktor penentu upaya peningkatan status kesehatan masyarakat Tujuan penelitian ini mengetahui analisis mutu pelayanan kesehatan dengan kepuasan pasien di puskesmas rawat inap kabupaten pasaman tahun 2019. Jenis penelitian ini adalah deskriptif analitik dengan desain crossectional study. Sampel penelitian adalah 195 responden di PKM Rawat Inap Kabupaten Pasaman. Untuk mengetahui pengaruh mutu pelayanan kesehatan dengan kepuasan pasien dilakukan analisis dengan uji chis-quare dan Uji Regresi Logistik Berganda. dengan derajat kepercayaan $95 \%$. Hasil penelitian menunjukkan setelah dilakukan analisis dengan menggunakan uji chi-square diperoleh ada hubungan reliability $(0,023)$, responsiveness $(0,018)$, assurances $(0,009)$, empathy $(0,005)$, tangibles $(0,0005)$ dengan Kepuasan Pasien di PKM rawat inap Kabupaten Pasaman tahun 2019. Hasil multivariate diperoleh dari 5 variabel, 1 variabel yang berpengaruh terhadap kepuasan pasien yaitu tangibles (0,0005). Kepada Petugas Kesehatan dapat mengidentifikasi dan mengevaluasi mutu pelayanan kesehatan dengan tingkat kepuasan pasien terutama di Puskesmas.
\end{abstract}

Kata kunci $\quad$ : Mutu Pelayanan Kesehatan, Kepuasan Pasien 


\section{PENDAHULUAN}

Kesehatan menurut Dr. White merupakan keadaan normal pada sesorang yang tidak memiliki keluhan atau absennya gejala-gejala penyakit yang diidentifikasi secara medis pada saat proses pemeriksaan berlangsung. Kesehatan merupakan investasi, hak, dan kewajiban setiap manusia (WHO, 2012). Kesehatan sebagai HAM secara tegas di amanatkan oleh UUD 1945, dimana dinyatakan bahwa setiap orang berhak hidup sejahtera lahir dan bathin, bertempat tinggal, dan mendapatkan lingkungan hidup yang baik dan sehat serta berhak memperoleh pelayanan kesehatan.(Tando et al, 2013).

Dalam Indonesia Sehat 2025 diharapkan masyarakat memiliki kemampuan menjangkau pelayanan kesehatan yang bermutu dan dan juga memperoleh jaminan kesehatan, yaitu masyarakat mendapatkan perlindungan dalam memenuhi kebutuhan dasar kesehatannnya. Diharapkan dengan terwujudnya lingkungan dan prilaku hidup sehat serta meningkatkan kemampuan masyarakat dalam memperoleh pelayanan kesehatan yang bermutu, maka akan dapat dicapai derajat kesehatan individu,keluarga dan masyarakat yang setingginya. (Tando et al, 2013). Salah satu bentuk fasilitas pelayanan kesehatan untuk masyarakat yang diselenggarakan oleh pemerintah adalah puskesmas.

Pelayanan kesehatan merupakan suatu sistem yang terdiri dari berbagai komponen yang saling terkait, saling tergantung, dan saling mempengaruhi antara satu dengan lainnya. Mutu pelayanan kesehatan di puskesmas dan rumah sakit adalah produk akhir dari interaksi dan ketergantungan yang rumit antara berbagai komponen atau aspek pelayanan (Bustami 2011).
Puskesmas adalah suatu unit pelayanan kesehatan yang merupakan ujung tombak dalam bidang kesehatan dasar. Sebuah Puskesmas dituntut untuk lebih bermutu sesuai dengan masalah kesehatan masyarakat yang potensial berkembang di wilayah kerjanya masing-masing.

Semakin berkembangnya masyarakat kelas menengah maka tuntutan untuk mendapatkan pelayanan kesehatan yang lebih bermutu juga meningkat. Sehingga untuk menghadapi hal itu diupayakan suatu program menjaga mutu pelayanan kesehatan dengan tujuan antara lain memberikan kepuasan kepada masyarakat (Efendi et al, 2013).

Fungsi Puskesmas yang sangat berat dalam memberikan pelayanan kepada masyarakat dihadapkan pada beberapa tantangan dalam hal sumber daya manusia dan peralatan kesehatan yang semakin canggih, namun harus tetap memberikan pelayanan yang terbaik (Tetria, 2016). Puskesmas yang memiliki rawat inap diberi tambahan sumber daya untuk menyelenggarakan pelayanan rawat inap, sesuai pertimbangan kebutuhan pelayanan kesehatan (PMK no 75, 2014).

Mutu pelayanan kesehatan adalah derajat dipenuhinya kebutuhan masyarakat atau perorangan terhadap asuhan kesehatan yang sesuai dengan standar profesi yang baik dengan pemanfaatan sumber daya secara wajar, efisien, efektif dalam keterbatasan kemampuan pemerintah dan masyarakat, serta diselenggarakan secara aman dan memuaskan pelanggan sesuai dengan norma dan etika yang baik (Azwar 2010).

Mutu pelayanan kesehatan dapat dinilai berdasarkan 5 dimensi utama yang berorientasi pada pelanggan yaitu 5 dimensi mutu pelayanan kesehatan, 
yaitu reliabilitas (reliability), daya tanggap (responsiveness), jaminan (insurance), empati (empathy), bukti fisik atau bukti langsung (tangible). Dari lima dimensi tersebut terdapat beberapa indikator dimensi yang harus diperhatikan dalam pelayanan kesehatan untuk meningkatkan kepuasan dan memenuhi harapanharapan pasien, yaitu: ketepatan waktu, akurasi pelayanan, kesopanan dan keramahan, tanggung jawab, kelengkapan, kemudahan mendapat pelayanan, variasi model pelayanan, pelayanan pribadi, kenyamanan, dan atribut pendukung lainnya (Bustami 2011).

Meesala, J. Paul (2018) menyatakan bahwa aspek terpenting yang harus dipusatkan pada manajemen di fasilitas kesehatan yaitu pengiriman layanan tepat waktu, karyawan yang peduli, akurasi penagihan, komunikasi yang tepat mengenai waktu pemberian layanan, ketepatan waktu, dan kemauan karyawan untuk membantu pasien. Dimensi mutu pelayanan kesehatan menunjukkan pada tingkat kesempurnaan pelayanan kesehatan dalam menimbulkan rasa puas pada diri setiap pasien. Semakin sempurna kepuasaan tersebut, semakin baik pula mutu pelayanan kesehatan.

Kepuasan pasien dalam menilai mutu atau pelayanan yang baik, merupakan pengukuran penting yang mendasar bagi mutu pelayanan. Hal ini karena memberikan informasi terhadap suksesnya pemberi pelayanan bermutu dengan nilai dan harapan pasien yang di kehendaki. Menurut John W et al (2010) mengukur kepuasan harus dari harapan pelanggan, preferensi mengenai berbagai dimensi kualitas produk dan layanan, persepsi mereka mengenai seberapa baik perusahaan yang memenuhi harapan mereka.

Ketidakpuasan pasien timbul karena terjadinya kesenjangan harapan pasien denga kinerja pelayanan kesehatan yang dirasakan sewaktu menggunakan pelayanan kesehatan. Suatu komunikasi yang iklas, tulus dan penuh perhatian, merupakan komunikasi yang sangat efektif untuk menimbulkan suatu suasana yang saling mempercayai, saling menghargai, dan saling menghormati, yaitu, suatu suasana yang kondusif atau merubah harapan pasien yang telah lama terbentuk (Pohan, 2007).

Banyaknya keluhan-keluhan masyarakat tentang pelayanan kesehatan sering menciptakan persepsi negatif di masyarakat tentang kualitas pelayanan kesehatan, karena persepsi adalah pengalaman tentang objek, peristiwa atau hubungan-hubungan yang diperoleh dengan menyimpulkan informasi dan menafsirkannya (Notoatmodjo, 2010).

Hasil penelitian Aida Andriani (2017) menunjukkan bahwa terdapat hubungan mutu pelayanan kesehatan dengan kepuasan pasien $p$-value $=0$, $067<0,10$. Menurut penelitian Suci (2018) menunjukkan bahwa terdapat hubungan mutu pelayanan kesehatan dengan kepuasan pasien.

Penelitian Lita et al (2016) menyatakan bahwa mutu pelayanan berpengaruh terhadap kepuasan pasien yaitu persepsi bukti langsung $(\mathrm{p}=0,038$ $\operatorname{Exp}(B)=0,485)$, dan persepsi biaya $(\mathrm{p}=0,010 \operatorname{Exp}(B)=0,381)$. Saeed et al (2018) juga menyatakan dalam penelitian meta analysis, dinyatakan bahwa ada pengaruh mutu pelayanan kesehatan (tangibles, realibility, assurance, empathy and responsibilitiy) dengan kepuasan pasien $(\mathrm{P}<0,01)$. Hal ini terlihat dari dimensi kulaitas pelayanan yang negatif, yang menyatakan bahwa 
kualitas layanan kesehatan di Iran belum memuaskan pasien dan perlu ditingkatkan.

Kabupaten Pasaman merupakan salah satu dari 19 kabupaten/kota yang ada di Provinsi Sumatera Barat yang luasnya $9,33 \%$ dari luas provinsi Sumbar. Kabupaten Pasaman sendiri mempunyai 12 kecamatan dan 62 nagari dan 16 Puskesmas yang 5 diantaranya merupakan puskesmas rawat inap, yaitu PKM Rao, PKM Tapus, PKM Cubadak, PKM Bonjol dan PKM Ladang Panjang. Pada tahun 2017 terdapat 3.386 kunjungan, namun pada tahun 2018 meningkat menjadi 4.029 kunjungan (Profil Kesehatan Kabuapten Pasaman, 2018).

Jumlah kunjungan menjadi meningkat dikarenakan adanya regulasi dari BPJS yang mengharuskan masyarakat untuk melakukan pengobatan ke fasilitas kesehatan tingkat pertama yaitu puskesmas terdekat ditempat mereka tinggal sebelum rujuk ke rumah sakit. Karena pelayanan kesehatan harus dilakukan secara berjenjang sesuai dengan kebutuhan medisnya serta dana kapitasi JKN di FKTP sudah ditetapkan sekurang - kurangya $60 \%$ maka dana ini harus dimanfaatkan untuk jasa pelayanan dan biaya operasional pada FKTP. Hal ini dimaksudkan untuk meningkatkan kualitas pelayanan kesehatan bagi peserta BPJS Kesehatan (BPJS, 2015).

Sesuai survey awal yang dilakukan ternyata walaupun jumlah kunjungan banyak, ternayata jika dilihat dari lima dimensi mutu pelayanan kesehatan (Reliability , Responsive, Assurance, Emphaty, Tangible) Terhadap 15 responden maka 11 dari 15 responden menyatakan tidak puas terhadap pelayanan yang di berikan oleh Puskesmas rawat inap yang ada di
Kabupaten Pasaman. Temuan lain yaitu 15 orang pasien yang berkunjung ke Puskesmas rawat inap, 9 orang responden mengeluhkan tentang kualitas pelayanan yang diberikan dimana lamanya waktu tunggu, prosedur pelayanan yang terkesan ribet dan cukup merepotkan bagi masyarakat. Berdasarkan uraian dan hasil perbandingan diatas peneliti tertarik untuk melakukan penelitian tentang "Analisis Faktor yang Mempengaruhi Mutu Pelayanan Kesehatan Terhadap Kepuasan Pasien Di Puskesmas Rawat Inap Kabupaten Pasaman Tahun 2019”.

\section{METODE PENELITIAN}

Penelitian ini merupakan jenis penelitian deskriptif analitik dengan menggunakan desain crossectional study. Penelitian ini dilaksanakan pada bulan Juni - Juli di Puskesmas Rawat Inap Kabupaten Pasaman. Populasi dalam penelitian ini adalah 4.029 responden dengan sampel 195 responden. Teknik pengambilan sampel dengan menggunakan Proportional sampling. Alat ukur yang digunakan adalah kuesioner yang terdiri dari kuesioner tentang mutu pelayanan dan kepuasan pasien (5 dimensi). Analisa data menggunakan Univariat dan Bivariat yaitu dengan Uji Chis- Square dan Mulitvariat Uji Regresi Logistik Berganda.

\section{HASIL DAN PEMBAHASAN Analisis Univariat}

Pada penelitian ini akan membahas tentang hasil univariat Sesuai dengan hasil penelitian bahwa distribusi frekuensi dapat dilihat pada tabel 1. Pada tabel 1 didapatkan bahwa sebagian besar distribusi frekuensi lebih dari separuh responden yaitu sebanyak 113 responden (57,9\%) menyatakan kehandalan petugas baik. 
TABEL 1. DISTRIBUSI FREKUENSI MUTU PELAYANAN KESEHATAN TERHADAP KEPUASAN PASIEN

\begin{tabular}{|c|c|c|}
\hline Kehandalan (reliability) & Frekuensi & Persentase (\%) \\
\hline Kurang Baik & 82 & 42,1 \\
\hline Baik & 113 & 57,9 \\
\hline Total & 195 & 100,00 \\
\hline $\begin{array}{c}\text { Daya tanggap } \\
\text { (responsiveness) }\end{array}$ & Frekuensi & Persentase $(\%)$ \\
\hline Kurang Baik & 60 & 30,8 \\
\hline Baik & 135 & 69,2 \\
\hline Total & 195 & 100,00 \\
\hline Jaminan (assurance) & Frekuensi & Persentase (\%) \\
\hline Kurang Baik & 79 & 40,5 \\
\hline Baik & 116 & 59,5 \\
\hline Total & 195 & 100,00 \\
\hline Empati (empathy) & Frekuensi & Persentase (\%) \\
\hline Kurang Baik & 80 & 41 \\
\hline Baik & 115 & 59 \\
\hline Total & 195 & 100,00 \\
\hline Wujud fisik (tangibles) & Frekuensi & Persentase (\%) \\
\hline Kurang Baik & 82 & 42,1 \\
\hline Baik & 113 & 57,9 \\
\hline Total & 195 & 100,00 \\
\hline Kepuasan Pasien & Frekuensi & Persentase (\%) \\
\hline Kurang puas & 69 & 35,4 \\
\hline Puas & 126 & 64,6 \\
\hline Total & 195 & 100,00 \\
\hline
\end{tabular}

Lebih dari separuh responden yaitu sebanyak 135 responden $(69,2 \%)$ menyatakan daya tanggap petugas baik. Lebih dari separuh responden yaitu sebanyak 116 responden $(59,5 \%)$ menyatakan jaminan dari petugas baik. Lebih dari separuhresponden yaitu sebanyak 115 responden $(59 \%)$ menyatakan empati petugas baik. Lebih dari separuhresponden yaitu sebanyak 113 responden $(57,9 \%)$ menyatakan wujud fisik petugas baik. Lebih dari separuhresponden yaitu sebanyak 126 responden $(64,6 \%)$ menyatakan puas dalam pelayanan.

\section{Analisa Bivariat}

Pada analisa bivariat bertujuan untuk melihat hubungan antara variabel independen dan dependen. Dalam penelitian ini peneliti ingin melihat hubungan mutu pelayanan kesehatan terhadap kepuasan pasien. Hal ini dapat dilihat pada tabel 2 .

\section{Hubungan Kehandalan terhadap Kepuasan Pasien}

Berdasarkan tabel 2, diperoleh nilai secara statistik dengan uji $C h i-$ Square yaitu p-value $=0,023$. Ini menunjukkan bahwa ada hubungan antara kehandalan dengan kepuasan pasien.

Hal ini didapatkan karena Kehandalan (reliability) dinilai paling penting oleh para pelanggan atau pasien berbagai industry jasa. Karena sifat produk jasa yang non standardized output,dan produknya juga sangat tergantung dari aktivitas manusia sehingga akan sulit mengharapkan output yang konsisten.

Saeed et al (2018) juga menyatakan dalam penelitian meta analysis, dinyatakan bahwa ada pengaruh mutu pelayanan kesehatan (tangibles, realibility, assurance, empathy and responsibilitiy) dengan kepuasan pasien $(\mathrm{P}<0,01)$. 
Menurut asumsi peneliti, pasienyang menilai petugas tidak handal dalam memberikan pelayanan cenderung tidak puas dengan pelayanan yang diberikan. Kondisi ini dipengaruhi oleh kemampuan petugas dalam menilai dan bertindak secara cepat,tepat dan akurat. Ketepatan dan keakuratan petugas dalam memberikan pelayanan kesehatan menjadi penentu dalam mencapai kepuasan padapasien, apabila hal ini terpenuhi maka harapan pasien terhadap pelayanan kesehatan akan terpenuhi dan akan meningkatkan kepuasan pasien terhadap pelayanan yangdiberikan.

\section{Hubungan Daya tanggap terhadap Kepuasan Pasien}

Berdasarkan tabel 2, diperoleh nilai secara statistik dengan uji $\mathrm{Chi}$ -
Square yaitu p-value=0,018. Ini menunjukkan bahwa ada hubungan antara daya tanggap dengan kepuasan pasien.

Daya tanggap dimasukkan kedalam kemampuan petugas kesehatan menolong pelanggan dan kesiapannya melayani sesuai produser dan bisa memenuhi harapan pelanggan. Dimensi ini merupakan penilaian mutu pelayanan yang paling dinamis. Harapan pelanggan terhadap kecepatan pelayanan cenderung meningkat dari waktu ke waktu sejalan dengan kemajuan teknologi dan informasi kesehatanyang dimiliki oleh pelanggan.

Hasil penelitian ini sesuai dengan penelitian Mai Yona (2016) yang menyatakan bahwa ada hubungan daya tanggap dengan kepuasan pasien (pvalue $=0,008<0,05)$. Penelitian

TABEL 2. FAKTOR YANG BERHUBUNGAN DENGAN KEPUASAN PASIEN DI PUSKESMAS RAWAT INAP KABUPATEN PASAMAN 2019

\begin{tabular}{|c|c|c|c|c|c|c|c|c|}
\hline \multirow{3}{*}{ Kehandalan } & \multicolumn{4}{|c|}{ Kepuasan Pasien } & & & \multirow{3}{*}{ OR $(95 \% \mathrm{CI})$} & \multirow{3}{*}{ p Value } \\
\hline & \multicolumn{2}{|c|}{$\begin{array}{l}\text { Tidak } \\
\text { Puas. }\end{array}$} & \multicolumn{2}{|c|}{ Puas } & \multicolumn{2}{|c|}{ Total } & & \\
\hline & $\mathrm{n}$ & $\frac{1 \%}{\%}$ & $\mathrm{n}$ & $\%$ & $\mathrm{~N}$ & $\%$ & & \\
\hline Kyrang Baik. & 37 & 45,1 & 45 & 54,9 & 82 & 100 & \multirow{3}{*}{$\begin{array}{c}2,081 \\
(1,145-3,782)\end{array}$} & \multirow{3}{*}{0,023} \\
\hline Baik. & 32 & 28,3 & 81 & 71,7 & 113 & 100 & & \\
\hline \multirow[t]{2}{*}{ Total } & 69 & 35,4 & 126 & 64,6 & 195 & 100 & & \\
\hline & \multicolumn{4}{|c|}{ Kepuasan Pasien } & \multirow{2}{*}{\multicolumn{2}{|c|}{ Total }} & \multirow{3}{*}{ OR $(95 \% \mathrm{CI})$} & \multirow{3}{*}{ p Value } \\
\hline \multirow[t]{2}{*}{ Daya Tanggap } & \multicolumn{2}{|c|}{$\begin{array}{l}\text { Tidak } \\
\text { Puas. }\end{array}$} & \multicolumn{2}{|c|}{ Puas } & & & & \\
\hline & $n$ & $\%$ & 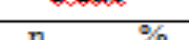 & $\%$ & $\mathrm{~N}$ & $\%$ & & \\
\hline Kurang Baik. & 29 & 48,3 & 31 & 51,7 & 60 & 100 & \multirow{3}{*}{$\left(1,187^{2,222}-4,158\right)$} & \multirow{3}{*}{0,018} \\
\hline Baik. & 40 & 29,6 & 95 & 70,4 & 135 & 100 & & \\
\hline Total & 69 & 35,4 & 126 & 64,6 & 195 & 100 & & \\
\hline \multirow{3}{*}{ Jappinan } & \multicolumn{4}{|c|}{ Kepuasan Pasien } & \multirow{2}{*}{\multicolumn{2}{|c|}{ Total }} & \multirow{3}{*}{ OR $(95 \%$ CI $)$} & \multirow{3}{*}{ p Value } \\
\hline & \multicolumn{2}{|c|}{$\begin{array}{l}\text { Tidak } \\
\text { Puas }\end{array}$} & \multicolumn{2}{|c|}{ Puas } & & & & \\
\hline & $n$ & $\%$ & $\mathrm{n}$ & $\%$ & $\mathrm{~N}$ & $\%$ & & \\
\hline \multirow{2}{*}{$\begin{array}{l}\text { Kurang Baik. } \\
\text { Bajk. }\end{array}$} & 37 & 46,8 & 42 & 53,2 & 79 & 100 & \multirow{3}{*}{$\begin{array}{c}2,312 \\
(1,268-4,217)\end{array}$} & \\
\hline & 32 & 27,6 & 84 & 72,4 & 116 & 100 & & 0,009 \\
\hline Total & 69 & 35,4 & 126 & 64,6 & 195 & 100 & & \\
\hline & & Kepua & a. Pas & & & & & \\
\hline Empati & & $\begin{array}{l}\text { dak } \\
\text { has. }\end{array}$ & & & & & OR $(95 \% \mathrm{CI})$ & p Value \\
\hline & $\mathrm{n}$ & $\%$ & $\mathrm{n}$ & $\%$ & $\mathrm{~N}$ & $\%$ & & \\
\hline Kyrang Baik. & 38 & 47,5 & 42 & 52,5 & 80 & 100 & 2,452 & \\
\hline Baits. & 31 & 27 & 84 & 73 & 115 & 100 & $(1,343-4,475)$ & 0,005 \\
\hline Total & 69 & 35,4 & 126 & 64,6 & 195 & 100 & & \\
\hline & & Kepua & (Pas & & & & & \\
\hline Wuind Fisik & & $\begin{array}{l}\text { dak } \\
\text { has. }\end{array}$ & & & & & OR $(95 \% \mathrm{CI})$ & p Value \\
\hline & $\mathrm{n}$ & $\%$ & $\mathrm{n}$ & $\%$ & $\mathrm{~N}$ & $\%$ & & \\
\hline Kurangerit & 47 & 57,3 & 35 & 42,7 & 82 & 100 & 5,555 & \\
\hline Baik. & 22 & 19,5 & 91 & 80,5 & 113 & 100 & $(2,932-10,524)$ & 0,0005 \\
\hline Total & 69 & 35,4 & 126 & 64,6 & 195 & 100 & & \\
\hline
\end{tabular}


Idris (2012) juga menyatakan bahwa ada hubungan antara hubungan daya tanggap dengan kepuasan pasien (pvalue $=0,016<0,05)$.

Pasien yang menyatakan bahwa petugas mampu menunjukkan daya tanggap yang baik dalam memberikan pelayanan cenderungmenyatakan puas dengan pelayanan yang diberikan. Begitu pula sebaliknya pasien yang menyatakan bahwa petugas tidak mampu menunjukkan daya tanggap yang baik pada saat memberikan pelayanan cenderung untuk tidak puas dengan pelayanan yangdiberikan.

\section{Hubungan Jaminan terhadap Kepuasan Pasien}

Berdasarkan tabel 2, diperoleh nilai secara statistik dengan uji ChiSquare yaitu p-value=0,009. Ini menunjukkan bahwa ada hubungan antara jaminan dengan kepuasan pasien.

Jaminan dari perawat disini dapat diwujudkan dengantingkah lakuyang baikolehperawatdengan cara selalu menyapa pasien, selalu bersikap ramah tamah dan sopan dalam memberikan layanan (Putri, 2016; Pohan, 2007).

Sejalan dengan penelitian Olgun Kitapci et al (2014) menunjukkan bahwa terdapat hubungan jaminan dengan kepuasan pasien (Pvalue $=0,000<0,05)$. Banyaknya responden yang menyatakan jaminan petugas baik cendrung untuk merasa puas dalam hal kepuasan pasien. dan sebaliknya jaminan petugas kurang baik pasien merasa tidak puas. Hal ini bisa didapatkan karena pasien merasa kurang mendapatkan perhatian khusus dari petugas dan kurang terciptanya keakraban dengan petugas.

\section{Hubungan Empati terhadap Kepuasan Pasien}

Berdasarkan tabel 2, diperoleh nilai secara statistik dengan uji ChiSquare yaitu p-value=0,005. Ini menunjukkan bahwa ada hubungan antara empati dengan kepuasan pasien.

Kepeduliankepada pasien dalam memberikan pelayanan dapat berupa memberikan motivasi kepada pasien ataupun dorongan agar pasien semangat dalam pelayanan. Hal tersebut sangat penting untuk meningkatkan kepuasan pasien (Mosadeghrad, 2014).

Sejalan dengan penelitian Olgun Kitapci et al (2014) menunjukkan bahwa terdapat hubungan empati dengan kepuasan pasien (Pvalue $=0,000<0,05)$. empati bisa memudahkan dalam melakukan hubungan komunikasi yang baik, perhatian pribadi dan memahami kebutuhan para pelanggan. Responden yang menyatakan empati petugas kurang baik, cendrung untuk merasa tidak puas dalam hal pelayanan. Rasa tidak puas itu muncul karena kurangnya waktu untuk berkonsultasi atau petugas terlalu sedikit menjelaskan kepada pasien tentang penyakitnya sehingga pasien merasa cemas akan penyakit yang dialaminya. Ketidakpuasan itu juga muncul karena petugas masih ada yang kurang ramah dalam melayani pasien.

\section{Hubungan Wujud Fisik terhadap Kepuasan Pasien}

Berdasarkan tabel 2, diperoleh nilai secara statistik dengan uji $C h i-$ Square yaitu p-value=0,0005. Ini menunjukkan bahwa ada hubungan antara wujud fisik dengan kepuasan pasien. Bukti fisik atau bukti langsung merupakan ketersediaan sarana dan prasarana termasuk alat yang siap pakai serta penampilan karyawan atau staf yang menyenangkan.

Sejalan dengan penelitian 
Tabel 5.13

Pengaruh Mutu Pelayanan Kesehatan dengan Kepuasan Pasien di Puskesmas Rawat Inap Kabupaten Pasaman Tahun 2019

\begin{tabular}{ccccc}
\hline Variabel & N & P-Value & $\operatorname{Exp}(\boldsymbol{\beta})$ & R square \\
\hline Reliability & & & & \\
Responsiveness & & 0,200 & 0,649 & \\
Assurance & \multirow{2}{*}{195} & 0,772 & 0,893 & \\
Empathy & & 0,074 & 0,553 & 0,216 \\
Tangibles & & 0,0005 & 0,717 & \\
& & & 0,454 & \\
& & & & \\
\hline
\end{tabular}

Penelitian yang dilakukan Mitropoulos (2018) bahwa bukti fisik yang terlihat dari lingkungan rumah sakit mempunyai hubungan dengan kepuasan pasien.

Timbulnya ketidak puasan pasien disebabkan karena wujud fisik yang ada tidak diiringi dengan daya tanggap yang baik dari petugas. Walaupun petugas kesehatan memiliki penampilan bersih dan rapi, tetapi dari segi waktu ia tidak datang tepat waktu, keadaan ruangan yang kurang fentilasi, jadi secara wujud fisik pandangan pasien terhadap petugas kesehatan menjadi kurang baik artinya petugas kesehatan tidak siap dalam melayani pasien dan kurangnya kenyamanan di dalam ruangan rawat inap.

\section{Faktor Yang Mempengaruhi Mutu Pelayanan Kesehatan terhadap Kepuasan Pasien}

Berdasarkan hasil penelitian, ada 5 faktor yang mempengaruhi kepuasan pasien di puskesmas rawat inap kabupaten Pasaman tahun 2019. Kekuatan pengaruh secara keseluruhan adalah 21,6\% artinya kekuatan pengaruh secara keseluruhan masih lemah. Dari 5 variabel, didapatkan 1 variabel yang berpengaruh terhadap kepuasan pasien yaitu tangibles (wujud fisik) dengan $\mathrm{p}$-value $=0,0005<0,05$ artinya Ho ditolak yang berarti bahwa
Ada pengaruh tangibles dengan kepuasan pasien di Puskesmas Rawat Inap Kabupaten Pasaman tahun 2019. Sedangkan 4 variabel mempunyai pvalue > 0,05 artinya keempat variabel tersebut tidak mempunyai pengaruh yang signifikan dengan kepuasan pasien. Setelah dilakukan analisis lanjut diperoleh nilai kuat pengaruh $\exp (\beta)$ dari prilaku sebesar 0,454 artinya semakin bagus wujud fisik maka semakin tinggi pula tingkat kepuasan pasien terhadap pelayanan puskesmas sebesar $45,4 \%$.

Carinciet al (2015) menyatakan bahwa mutu pelayanan kesehatan merupakan dimensi inti dari kinerja sistem kesehatan dimana indikatornya sudah banyak tersedia. Mutu Pelayanan Kesehatan merupakan derajat dipenuhinya kebutuhan.

Menurut asumsi peneliti banyak responden yang menyatakan wujud fisik sudah baik namun masih ada responden melihat wujud fisik yang kurang baik yaitu penampilan petugas kurang rapi, peralatan makan yang ditumpuk dan belum dicuci serta ruangan yang kenyamanannya terasa sempit karena penataan ruangan yang kurang bagus. Karena penampilan tersebut pasien merasa kurang nyaman berkomunikasi dengan petugas.

Wujud fisikatau Tangible mutu pelayanan kesehatan sangat erat 
kaitannya untuk menilai suatu pelayan itu bernilaibaikatau tidak, karena Tangible erat kaitannya dengan kenyamanan pasien, misalnya saja sarana dan prasarana kesehatanyang kurang memadai, seperti bangunanyang tidakbagus,tempatmenungguantrianpeng obatan tidak ada, dll. Maka hal tersebut bisa membuat pasien tidak nyaman dalam menerimapelayanan, sehinggadapat membuat mutu pelayanan menjadi kurangbaik. Wujud fisik yang kurang baik dapat menyebabkan ketidaknyamanan bagi pasien. Maka dari itu petugas hendaknya memperhatikan penampilannya sehingga kelihatan rapi saat keruangan dan menjaga kebersihan tersebut maka pasien akan senang dan nyaman untuk berkomunikasi dengan petugas.Karena sesuai dengan hasil penelitian bahwa semakin bagus wujud fisik maka semakin tinggi pula tingkat kepuasan pasien terhadap pelayanan puskesmas.

\section{KESIMPULAN DAN SARAN}

Dapat menambah pengetahuan bagi responden tentang kualitas dan prosedur pelayanan kesehatan sehingga masyarakat mampu memahami bagaimana mutu pelayanan kesehatan di Puskesmas serta mampu menjalaninya dengan baik. Dan juga responden agar dapat terbuka dalam menilai dan menyampaikan apa yang dirasakan terkait pelayanan kesehatan di Puskesmas sebagai fasilitas pelayanan kesehatan seperti menyampaikan masukan sesuai dengan harapan serta kebutuhan responden agar mendapatkan pelayanan yang memuaskan dari kehandalan, ketanggapan, jaminan, kepedulian serta bukti fisik pelayanan kesehatan.

\section{UCAPAN TERIMA KASIH}

Terima kasih diucapkan kepada
LPPM STIKes Fort De Kock yang telah memfasilitasi penelitian ini. Selanjutnya, terima kasih juga dihaturkan kepada seluruh responden atas partisipasinya dalam terlaksananya penelitian ini.

\section{DAFTAR PUSTAKA}

Aliman \& Mohamad, 2016. Linking Service Quality, Patients' Satisfaction and Behavioral Intentions: An investigation on Private Healthcare in Malaysia. Journal Science Direct, Social and Behavioural Science. 224 , pp : 141-148.

Azwar, $\quad$ Saifuddin. 2010. MetodePenelitian. Yogyakarta: Pustaka Pelajar

Andriani,A. 2017.Hubungan Mutu Pelayanan Kesehatan dengan Kepuasan Pasien di Ruangan Poli Umum Puskesmas Bukittinggi. Journal Endurance, 2, 45-52

Badan Penyelenggara Jaminan Sosial. 2015. BPJS Pentingkan Kualitas Fasilitas Kesehatan Tingkat Pertama.

http://bpjs kesehatan.go.id [diakses tanggal 6 Mei 2019].

Bustami, 2011. Penjaminan mutu dan aseptabilitas Pelayanan Kesehatan \& Akseptabilitasnya. Jakarta: Erlangga

Carinci, Van Gool, Mainz, Pichora, Veillard, Januel, Arispe, Kim. 2015. Towards Actionable Intenrational Comparisons of Helath System Performance : expert revision of the OECD framework and quality indicators. International Journal for Quality in Helath Care, vol 27 (2), pp: 137-146.

Chinglin, Xirasagars, Laditka JN. 2004. Patient Perceptions of Service Quality in Group Versus Solo Practice Clinics. International 
Journal for Quality in Helath Care, vol 16 : Oxford University. Effendi, Rustam, dkk. 2013.Hubungan Mutu Pelayanan Kesehatan dengan Kepuasan Pasien Rawat Jalan di Puskesmas Aeng Towa Kabupaten Takalar. Universitas Hasanuddin.

Handayani, Fitri. 2016. Hubungan Kualitas Pelayanan Kesehatan Dengan Minat Pemanfaatan Ulang Puskesmas Pangi Kecamatan Parigi Utara Kabupaten Parigi Moutong. Palu: Universitas Tadulako

Hermanto,Dadang. 2010. Pengaruh Persepsi Mutu Pelayanan Kebidanan Terhadap Kepuasan Pasien Rawat Inap Kebidanan Di RSUD Dr. $\quad H$. Soemarno Sosroatmodjo Bulungan Kalimantan Timur. [Tesis] Program Study Magister Kesehatan Masyarakat Konsentrasi. Administrasi Dan Kebijakan Kesehatan Minat Manajemen Kesehatan Ibu dan anak. Program Pasca Sarjana Universitas Diponegoro. Semarang.

Idris, E. 2012. Hubungan Dimensi mutu Pelayanan dengan Tingkat Kepuasan Pasien di Ruangan Rawat Inap RSUD Pariaman Tahun 2012. Skripsi. Sumatera Barat.

Jabbar, Karmilasari. 2014. Hubungan Kualitas Pelayanan Dengan Minat Pemanfaatan Kembali Pelayanan Kesehatan Di Puskesmas Jongaya Kota Makassar. Makassar: Universitas Hasanuddin.

Lisa Setia, Ruslan Muhyi, Husaini .2016. Pengaruh Mutu Pelayanan Terhadap Persepsi Kepuasan Pasien Di Laboratorium
Puskesmas Kota Banjarbaru Tahun 2016 .Jurnal berkala kesehatan, Vol. 3, No. 1: 9-17

Monika, Chreisye and Paul. 2015. Hubungan antara Mutu Pelayanan Kefarmasian dengan Kepuasan Pasien Rawat Jalan di Puskesmas Teling Atas Kota Manando. Jurnal Ilmiah Farmasi : 4(4) pp 1-9.

Meesala,A.,\&Paul,J. 2018. Service Qualty,Consumer Satisfatction and Loyalty in Hospitals: Thinking for The Future. Journal of Retailing and Consumer Services, 40, 261-269.

Mitropoulos,P.,Vasileiou,K.,\& Mitropoulos,I.(2018).Understandi ng Quality and Satisfaction in Public Hospital Services: A nation wide Inpatint Survey in Greece. Journal of Retailing and Consumer Services, 40, 270-275.

Mosadeghrad, A. M. 2014. Factors Influencing Health care Service Quality. International Journal of Health Policy and Management, 3(2), 77-89.

Mullins, John W. Dan Orville C. Walker, JR. 2010. Marketing Management: A Strategic Decision-Making Approach, Seventh Edition. (New York: McGraw-Hill Companies Inc.)

Nofiana, H., \& Sugiarsi, S. 2011. Hubungan Mutu Pelayanan Pendaftaran dengan Kepuasan Pasien Rawat Jalan di Rumah Sakit PKU Muhammadiyah Karanganyar. Jurnal Kesehatan, 5(1), 90-106)

Notoatmodjo, 2012. Promosi kesehatan dan Perilaku Kesehatan. Jakarta:Rineka Cipta

Olgun, Ibrahim, Ceilan. 2014. The Impact Of Service Quality Dimension on Patient Satisfaction, Repurchase 
Intentions and Word Of Mouth Communication in the Public Helathcare Industry. Science Direct Journal, Social and Behaviour Science. 161-169.

Peraturan Menteri Kesehatan. 2014. PMK Nomor 75 tentang Pusat Kesehatan Masyarakat. Jakarta : Kementerian Kesehatan Republik Indonesia.

Pohan,S. Pohan.2007.Jaminan Mutu Layanan Kesehatan. Jakarta: EGC Pratiwi. Rezki Dini. 2016 Hubungan Kualitas Pelayanan dengan Minat Berkunjung Kembali Di Puskesmas Soropia Kecamatan Soropia Kabupaten Konawe. Universitas Halu Oleo

Putri, V. A. 2016. Hubungan mutu pelayanan kesehatan dengan kepuasan pasien di puskesmas pauh pariaman kota pariaman tahun 2016.Skripsi. STIkes Fort De Kock.

Respati, S. A. 2015. Hubungan Mutu Pelayanan Kesehatan dengan Tingkat

Kepuasan Pasien Rawat Inap di Puskesmas Halmahera Kota Semarang. Skripsi. Semarang : Universitas Negeri Semarang

Saeed Hosseini Teshnizi, Teamur Aghamolaei, Kobra Kahnouji, Seyyed Mehrdad Hosseini Teshnizi, And Jalil Ghani. Assessing quality of health services with the SERVQUAL model in Iran. A systematic review and meta-analysis .2018. International Journal for Quality in Health Care, 30(2), 82-89

Stephen, Tony, Summaya and Richard. Patient Satisfaction with Primary Health Care Service in the United Arab Emirates. International Journal For Quality in Helath. Vol 15 (3), pp : 241-249.

Sri. 2015. Hubungan antara Kualitas Pelayanan Rumah Sakit dengan Tingkat Kepuasan Pasien BPJS di Ruang Perwatan RSUD Sualltan Syarief Mohammad Alkadrie. Jurnal Keperawatan. Pp : 1-11

Suprianto, J. 2011. Pengukuran Tingkat Kepuasan Pelanggan. Jakarta:. Rineka Cipta

Tando.MNaomy, 2013. Organisasi dan Managemen Pelayanan Kesehatan. Jakarta:In Media

Trimurthy, Iga. 2008. Analisis Hubungan Persepsi Pasien Tentang Mutu Pelayanan Dengan Minat Pemanfaatan Ulang Pelayanan Rawat Jalan Puskesmas Pandanaran Kota Semarang. Semarang: Universitar Diponegoro

Wijono.D. 2010. Manajemen Mutu Pelayanan Kesehatan Teori, Strategidan aplikasi, Surabaya: Airlangga University Press.

WHO.2012. www.who.int.Anonim. 2012. Diaksestanggal :11 april 2019 